EISSN: 2706 -7947 ISSN: 2077- 4613

DOI: $10.36632 /$ mejas/2021.11.3.57

Journal homepage: www.curresweb.com

Pages: 774-784

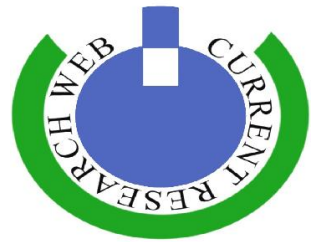

\title{
Effect of Vermicompost, (PGPR) and Humic Acid on Egyptian Cotton Yield in A Clayey Soils
}

\author{
Ahmed H. S. A. \\ Cotton Research Institute, Agricultural Research Center, Giza, Egypt
}

Received: 05 August $2021 \quad$ Accepted: 20 Sept. $2021 \quad$ Published: 25 Sept. 2021

\begin{abstract}
This investigation was conducted at Sakha Agriculture research station, Cotton Research Institute, Agric. Res. Center, Egypt, during 2018 and 2019 seasons to study the effect of vermicompost and the inoculation with some bacterial strains as bio-fertilizer (PGPR) and humic acid both separately or together with or without vermicompost on soil chemical and biological properties, cotton yield and some yield components, leaf chemical analysis and cotton fiber properties compared to the control at Giza 97 Egyptian cotton variety. The most important results can be summarized as follows: Adding vermicompost achieved the highest content of soil organic matter compared to the rest of the transactions under study Adding bacterial strains led to increase soil biological activity compared to the rest of the transactions, as well as the control treatments. This reflected directly on all the characters. The treatment of (PGPR) and humic acid in the presence of vermicompost increased the soil content of $\mathrm{N}, \mathrm{P}, \mathrm{K}$ elements along with the soil softness, soil total fungi, bacteria actinomycetes counts, as well as, boll weight, lint percentage, seed index and seed cotton yield (Kentar/fed.), the leaf chemical analysis, and fiber physical properties. All the treatments led to an increase in soil biological activity in terms of increasing the total bacterial, total Fungi counts. So, we can use this treatment safely to produce bio organic cotton. Generally, it could be concluded that the use of the treatment of spraying (PGPR) and humic acid in the presence of vermicompost is useful for the enhancement of soil chemical and biological properties. On the other hand, the pervious treatments decreased the degree of soil $\mathrm{pH}, \mathrm{EC}$ and the fiber yellowness characters which followed an opposite situation than the rest of fiber characters. While, influence of main factors was not significant on fiber elongation percentage. From all the results we can recommend the use of bio-fertilization with Egyptian cotton varieties, which means using clean fertilizer, decrease used the mineral fertilizer and decrease environmental pollution.
\end{abstract}

Keywords: Egyptian cotton, Organic, Humic acid, PGPR, Fiber quality, Eco-friendly, Vermicompost Yield and yield components, Fiber properties.

\section{Introduction}

In the modern cultivation, indiscriminate use of fertilizers, particularly the nitrogenous and phosphorus, has led to substantial pollution of soil, air and water the excessive use of these chemicals exerts deleterious effects on soil microorganism, affects the soil fertility and pollutes environment (Youssef and Eissa 2014). So, the high nitrogen fixing, phosphate isolates of Azotobacter, Azospirillum, Acetobacter and Pseudomonas were used as inoculants for cotton and it is effected on Plant height and boll weight were determined at the time of harvesting whereas survival rate of inoculated bacteria was identified as significant both for American cotton varieties. (ICOF 2010; Neeru et al., 2005 and Mitkees et al., 1996). While, (Shivalingaiah 2007) indicated that organic cotton production is expected to expand in response to increased demand for organic fibers. Thus, there is a need to study the effect of this fertilizers on the Egyptian cotton quality and quantity because our cottons have a unique fiber property besides our soil is suffering of lack of minerals since building the high dam as clarified by (Arafa and El-Gebaly 2007 and Arafa et al., 2013). So, we should focus on method helps us to increase the soil fertility, like bio organic fertilization. (Twewaadha and Alweendo 2007; Kevin 2003 and Shivalingaiah, 2007) founded that the organic cotton fertilizers like, 
vermicompost, humic acid solid manures and bio-fertilizers etc., provide necessary nutrients for plant, improve soil properties and decrease the soil $\mathrm{pH}$ that reflected on the crop growth and production. (Ambergerig 1993) defined the bio-fertilizers as inoculation with several soil bacteria and fungi notably the species of Pseudomonas, Bacillus, Penicillin and Aspergillus secrete organic acids and lower the $\mathrm{pH}$ which facilitate the solubility of mineral in the soil and added that Pseudomonas $s p$. are receiving worldwide attention under the broad general category known as plant growth promoting rhizobacteria (PGPR) or plant health promoting rhizobacteria. So, the use of bio-inoculants is beneficial in improving yield parameters (weight of bolls, number of bolls per plants and seed cotton yield) and fiber quality parameters (span length, uniformity ratio, micronaire value, tenacity and EIG) up to some extent. The utilization of (PGPR) in agriculture is continuously increasing as it offers an effective tool to replace the use of chemical fertilizers, pesticides and other harmful supplements. (Bhattacharyya and Jha, 2012 and Ansari et al., 2017 $7^{\mathrm{ab}}$ ) founded the growth promoting substances are produced in huge quantities by the action of these rhizosphere microorganisms that directly or indirectly influence the overall morphology and physiology of the crops. Recent advances in the field of sustainable development relies on the use and diversity of PGPR, their colonizing capability and the mechanism of action that may be used to facilitate their application as a dependable element in the management of sustainable agricultural system. (Heba and Rokaya 2015) found that, all the factors under the study led to an increase in soil biological activity in terms of increasing the total bacterial, total Fungi counts, $\mathrm{CO}_{2}$ evolution. Generally, it could be concluded that the use of the treatment (PGPR) and compost in the presence of rice straw is useful for the colored cotton, and enhancement of soil chemical and biological properties. (El. Maas et al., 2016). found that the effect of humic acid, compost tea and bio-fertilizer using two methods of application (foliar and soaking) on some chemical and physical soil properties under saline soil conditions. led to The soil $\mathrm{pH}$ and EC values decreased due to different treatments using soaking or foliar application. The lowest value of EC in soil reached (4.61 d s m) by applying humic acid as foliar application. The soil content of O.M increased in case of bio-fertilizer, humic acid and compost tea compared with control. (Mahmoud et al., 2019) recommended that, the use of organic manure in the form of cattle manure interacted with humic acid application on cotton plants led to increase the productivity of cotton plants in terms of quantity.

The main goal of the current study was effect of vermicompost and the inoculation with some bacterial strains and humic acid both separately on soil chemical and biological properties and cotton yield, yield components, leaf chemical analysis and cotton fiber properties.

\section{Materials and Methods}

Field Experiment was conducted to examine the influence of vermicompost, bio inoculants (PGPR), humic acid, and their combinations on yield and fiber quality of the Egyptian cotton cultivar Giza 97 This promising cross have toke (Giza 89 x R151) x Giza 86) x Giza 94) beginning from 2020 season and considered as a commercial variety at the Sakha Agriculture research station, Cotton Research Institute, Agricultural Research Center Giza Egypt during 2018 and 2019 growing seasons. The experiment was laid out in a split block design with 4 four replicates. The vermicompost application was occupied the main plot as a main factor with two levels (with vermicompost, without vermicompost), while; the others fertilizers treatments were distributed randomly in the sub plots. Net plot size was $3 \times 3.5 \mathrm{~m}$ with proper irrigation channels. Vermicompost was applied and mixed thoroughly the main plots, the following the fertilizer treatments were conducted in this study:

1) $100 \%$ mineral fertilizer ... control ${ }^{(1)}$ (recommended dose $60 \mathrm{~kg} \mathrm{~N} /$ feddan, $30 \mathrm{~kg} \mathrm{~K}_{2} /$ feddan, $15 \mathrm{~kg}$ $\mathrm{P}_{2} \mathrm{O}_{5} /$ feddan)

2) $50 \%$ of recommended $\ldots$ control $^{(2)}$

3) $50 \%$ of recommended + PGPR

4) $50 \%$ of recommended + Humic acid

5) PGPR + Humic acid

6) $100 \%$ mineral + Vermicompost

7) $50 \%$ mineral + Vermicompost

8) $50 \%$ mineral + PGPR + vermicompost

9) $50 \%$ mineral + Humic acid + Vermicompost 
10) PGPR + Humic acid + Vermicompost

\subsection{Vermicompost}

Vermicompost recommended dose $400 \mathrm{~kg} /$ feddan, it was collected from by Bio-fertilizers inoculum was prepared as Department of Microbiology of Soil and Water Research Institute, Agricultural Research Centre, Giza, Egypt. The results of these analyses are shown in Table (1)

Table 1: Some chemical properties of vermicompost used.

\begin{tabular}{|c|c|}
\hline Properties & Value vermicompost \\
\hline $\mathrm{pH}$ & 8.60 \\
\hline E.C $\left(\mathrm{d} 5 \mathrm{~m}^{-1}\right)$ & 3.11 \\
\hline Available $\mathrm{N}-\mathrm{NH}_{4}$ ppm & 9.31 \\
\hline Available N-No3 ppm & 36.81 \\
\hline Total Nitrogen & 836 \\
\hline Total Phosphors & 13500 \\
\hline Total Potassium & 15400 \\
\hline $\mathrm{Fe}$ & 15.30 \\
\hline $\mathbf{Z n}$ & 9.70 \\
\hline Mn & 3.30 \\
\hline $\mathbf{C u}$ & 1.70 \\
\hline
\end{tabular}

\subsection{These include PGPR}

Pseudomonas sp. and Bacillus subtilis); AMF (Rhizophagus intraradices); and PGPF (Trichoderma sp., and Aspergillus niger). Related to tailored compost, CSIC will provide the protocols for the production of a tailored compost consisted mainly of initial raw materials with specific $\mathrm{C} / \mathrm{N}$ ratio and inoculation mainly with Trichoderma sp., Azospirillum brasiliensis, and Aspergillus niger. Two formulated will be prepared at CSIC before sending to the other partners: a) microbial formulated consisted on a microorganism mix imbibed on bentonite, bacterial should reach $10^{(8)} \mathrm{ufc} / \mathrm{g}$, fungi should reach $10^{(5)} \mathrm{ufc} / \mathrm{g}$ and AMF (that will consist of a mix mixture of rhizospheric soil from trap Sorghum Bicolor L. containing spores, hyphae and mycorrhizal root fragments) with a 35 infective propagules per gram; b) tailor compost implemented with Trichoderma harzianum $10^{(4)} \mathrm{ufc} / \mathrm{g}$ and Azospirillum brasiliensis $10^{(7)} \mathrm{ufc} / \mathrm{g}$. At each site. produced by culture collection of Agric. Microbiology Dept., ARC, Giza, Egypt. PGPR concentration was adjusted to $1 \times 10^{8}(\mathrm{cfu} / \mathrm{gr})$ for all treatments and sprayed at 60,80 and 100 days in the recommended times of cotton fertilization.

\subsection{Humic Acid}

Is in black color and insoluble in water itself, it has high content of organic matter and humic acid, and is milled from leonardite or lignite sources. Application: It is the source of water soluble potassium humate, sodium humate, potassium fulvate. - It increase the organic matter in organic fertilizer formulations and sprayed. as a foliar spraying on cotton leaves using hand operated sprayer compressed at a low volume of 200 liters per feddan. The lower leaf surface was sprayed until wetted as well as the upper surface at 60,80 and 100 days. Humic acid is the active ingredient of actosol product, the natural organic fertilizer. The different constituents of actosol as reported by (Fataftah et al., 2001)

\subsection{Soil analysis}

The experimental field soil was sampled initially before conducting the experiment to determine its physical and chemical analyses according to (Jackson, 1973 \& 1976). The results of these analyses are shown in Table (2).

\section{The studied characters on cotton plant}

Yield and yield components: At harvest, samples of ten plants from the inner ridges of each subplot were taken at random to determine the following yield attributes:

- Boll weight $(\mathrm{g})=$ average for weight 50 bolls

- Lint percentage: Lint percentage $=\{$ Lint seed cotton weight $/$ seed cotton weight $\} \times 100$ 
- Seed index (100 seeds weight $(\mathrm{g}))$

- Seed cotton yield (Kentar/fed.). notes, 1 seed cotton Kentar $=157.5$ kilograms

Table 2: Some chemical, physical and mechanical properties of soil at Sakha Agriculture research station

\begin{tabular}{|c|c|c|}
\hline Properties & Season 2018 & Season 2019 \\
\hline Coarse sand $\%$ & 4.4 & 3.8 \\
\hline Fine sand\% & 25.6 & 24.3 \\
\hline Silt\% & 27.8 & 29.1 \\
\hline Clay & 42.2 & 42.8 \\
\hline Texture & 1.42 & 1.33 \\
\hline $\mathrm{CaCO}_{3}$ & 1.41 & 1.36 \\
\hline pH $(1: 2: 5)$ soil solution & 7.35 & 7.10 \\
\hline EC ds/m (soil paste) & 1.9 & 1.84 \\
\hline Total N \% & 0.091 & 0.041 \\
\hline Organic C \% & 0.86 & 0.78 \\
\hline \multicolumn{3}{|c|}{ Soluble Cations $\left(\mathrm{Megl}^{-1}\right)$} \\
\hline $\mathrm{Ca}++$ & 7.51 & 7.02 \\
\hline Mg++ & 4.56 & 7.89 \\
\hline $\mathrm{Na}+$ & 10.49 & 10.37 \\
\hline $\mathbf{K}+$ & 0.45 & 0.63 \\
\hline \multicolumn{3}{|c|}{ Soluble anions $\left(\mathrm{meg2}^{-1}\right)$} \\
\hline $\mathrm{Co}++$ & 0.00 & 0.00 \\
\hline Hco- & 2.11 & 2.29 \\
\hline Cl- & 9.16 & 9.04 \\
\hline So4 - & 11.30 & 11.28 \\
\hline
\end{tabular}

Note: (Sakha, Kafr El-Sheikh governorate 2018-2019)

\subsection{Chemical analysis}

Leaf chlorophyll (A, B) and carotenoids contents were determined in leaves according to (Arnon, 1949 and Rolbelen, 1957) respectively. While, total phenol was determined according to (Simon and Ross 1971).

\subsection{Fiber properties}

Micronaire value, maturity ratio (MR), upper half mean (UHM)mm, uniformity index (UI), reflected percent or brightness $(\mathrm{Rd}) \%$, yellowness degree $(+\mathrm{b})$, strength $(\mathrm{g} / \mathrm{tex})$ and elongation percentage were determined using HVI instrument system. according to (ASTM: D4605 1986). All properties were measured under standard conditions of $(65 \pm 5 \%)$ relative humidity and $\left(20 \pm 2 \mathrm{c}^{\circ}\right)$ room temp.

\subsection{Statistical analysis}

The data were statistically analyzed according to (Snedecor and Cochran 1981). The data was computed using the M-Stat $6.311(1998-2005)$ as statistical program, to test differences among studied mean values of treatments, the least significant difference (L.S.D.) at 0.05 level of probability was used.

\section{Results and Discussion}

Data in Table (3) Show some chemical properties of the clay soil after cotton harvesting as affected by different applied treatment.

\subsection{Soil chemical properties}

I. Soil organic matter (SOM): After cotton harvesting as affect by the tested bio-fertilizer treatments with or without vermicompost is shown in Table (3): Results revealed that only the incorporation either with or without vermicompost increased the soil organic matter. 
II. Soil (E.C) and soil (pH): All treatments with vermicompost decreased both EC and $\mathrm{pH}$ as compared to the treatments without vermicompost. However, the treatment received (PGPR + Humic acid + vermicompost) gave the least EC $\left(1.31\right.$ and $\left.1.30 \mathrm{dSm}^{-1}\right)$. Also, the least $\mathrm{pH}$ degree $(6.97$ and $6.86)$ in the same treatment (50\% mineral + Humic acid + vermicompost) in 2018 and 2019 seasons respectively.

III. Soil Available N, P and K: Soil available N, P \& K, exhibited higher values due all the treatments with vermicompost over the control treatment. Nevertheless, the highest soil available N, P and K values were recorded by the treatment received (PGPR + Humic + Vermicompost). The corresponding values were (1.42 and 1.44) $\mathrm{mg} \mathrm{N} \mathrm{kg}^{-1}$ soil, (0.87 and 0.88$) \mathrm{mg} \mathrm{P} \mathrm{kg}^{-1}$ soil and $(0.63$ and 0.66$) \mathrm{mg} \mathrm{K}$ $\mathrm{kg}^{-1}$ soil in 2018 and 2019 seasons respectively.

IV. Soil biological activity: Soil biological activity parameters under different treatments of PGPR and humic mixed with or without vermicompost are aforementioned in Table (4) results revealed that the treatment of PGPR and humic with vermicompost gave the highest values of all soil biological activity parameters. i.e., total bacteria count $\left(42 \times 10^{7}\right.$ and $\left.43 \times 10^{7}\right) \mathrm{cfu} \mathrm{g}^{-1}$ dry soil, total Fungi $(62.1$ x $10^{4}$ and $\left.67.9 \times 10^{4}\right) \mathrm{cfu} \mathrm{g}^{-1}$ dry soil, total actinomycetes $\left(69.1 \times 10^{3}\right.$ and $\left.70 \times 10^{3}\right) \mathrm{cfu} \mathrm{g}^{-1}$ dry soil and (34 - 34.3) $\mathrm{mg} \mathrm{CO}_{2} 100 \mathrm{~g}$ dry soil day ${ }^{-1}\left(\mathrm{CO}_{2}\right.$ evolution), in 2018 and 2019 seasons respectively. While; (50\% of recommended) without vermicompost, gave the lowest values which recorded total bacteria count (11 and 12) x $10^{7} \mathrm{cfu} \mathrm{g}^{-1}$ dry soil, total Fungi $\left(20 \times 10^{4}\right.$ and $\left.22 \times 10^{4}\right)$ cfu g-1 dry soil, total actinomycetes (17 and 16) x $10^{3} \mathrm{cfu} \mathrm{g}^{-1}$ dry soil and (15.50 and 15.1) $\mathrm{mg} \mathrm{CO}_{2} 100 \mathrm{~g}^{-1}$ dry soil day ${ }^{-1}$ ( $\mathrm{CO}_{2}$ evolution), in 2018 and 2019 seasons respectively Similar results were in agreement with: (Waller and Duncan 1969).

\subsection{Leaf chemical analysis}

The Leaf chlorophyll content A, B and carotenoids as well as Phenol (mg/g dry weight) were illustrated in Table (5) showed that 2018 season was little bit higher than 2019 season and the vermicompost results was better than those without vermicompost application for all the characters under the study. The treatment (PGPR+ Humic acid) surpassed the rest whatever been the character under the study. Contrary, the lowest levels from all the characters were obtained from the treatment $50 \%$ mineral fertilizer ( $\mathrm{control}^{2}$ ). Also, its noticeable that the treatment $(50 \%$ mineral fertilizer + PGPR was usually higher than the treatment (50\% mineral fertilizer + Humic acid) in case of vermicompost application. While, those treatments converse their trend without vermicompost application, this true whatever was the character or the studying season.

3.3. Yield and yield compounds traits: The influence of vermicompost, fertilizers and interaction between them on Lint percentage and Seed Index were presented in Table (6). The treatment (PGPR + humic acid) increased significantly the boll weight in both seasons with vermicompost which reflected directly on seed cotton yield per feddan, because boll weight is one of the yield components. The pervious treatment increased boll weight by $(0.20$ and $0.25 \mathrm{~g})$ in 2018 and 2019 respectively under the soil applied with vermicompost. While, it increased the seed cotton yield by ( 1 and $1.1 \mathrm{kentar} / \mathrm{fedan})$ for the same treatment in both seasons respectively, comparing to control ${ }^{1}$ (recommended) because it receives adequate nutrient than the other treatments which reflected directly on both the boll weight, seed index and the lint percentage as mentioned above similar trend was stated by (Mahmod et al., 2019 and Ahmed et al., 2020).

As to Lint percentage, data signified that the interaction between vermicompost and the fertilizers was not reach the significant level in both seasons. Thus, we emphasis in the dissection of the main factors instead of the interactions. As to the vermicompost factor, the values of lint percentage were $(38.5 \%$ and $38.3 \%)$ for the soil applied with vermicompost and $(37.1 \%$ and $36.5 \%)$ with the soil was not applied respectively. Thus, the application with vermicompost gave an increase in lint percentage by $(1.6 \%)$ than the soil without vermicompost. Considering, the fertilizers treatments, it could be arranged in ascending order as follows the (PGPR + Humic acid), control ${ }^{2},(50 \%$ mineral fertilizer + Humic acid), (50\% mineral fertilizer + PGPR) and control ${ }^{1}$ in case of soil applied with vermicompost. On the other hand, the soil was not applied with vermicompost followed the same trend with replacing the treatment with $(50 \%$ of recommended + PGPR). This may be attributed to that the 
Middle East J. Appl. Sci., 11(3): 774-784, 2021

Table 3: Some chemical properties of the soil after harvesting cotton as affected by PGPR, humic acid with or without vermicompost in 2018 and 2019 seasons.

\begin{tabular}{|c|c|c|c|c|c|c|c|c|c|c|c|c|c|}
\hline \multirow{3}{*}{ Treatment } & & \multirow{2}{*}{\multicolumn{2}{|c|}{ SOM }} & \multirow{2}{*}{\multicolumn{2}{|c|}{$\begin{array}{c}\text { E.C } \\
\left(\mathrm{dS} \mathrm{m}^{-1}\right)\end{array}$}} & \multirow{2}{*}{\multicolumn{2}{|c|}{ pH }} & \multicolumn{6}{|c|}{ Available N, P and $K \%$} \\
\hline & & & & & & & & \multicolumn{2}{|c|}{$\mathbf{N}$} & \multicolumn{2}{|c|}{$\mathbf{P}$} & \multicolumn{2}{|c|}{$\mathbf{K}$} \\
\hline & Seasons & 2018 & 2019 & 2018 & 2019 & 2018 & 2019 & 2018 & 2019 & 2018 & 2019 & 2018 & 2019 \\
\hline \multirow{5}{*}{$\begin{array}{c}\text { Without } \\
\text { vermicompost }\end{array}$} & Control 100\% & 28.1 & 27.9 & 1.51 & 1.58 & 7.39 & 7.16 & 1.14 & 1.18 & 0.62 & 0.59 & 0.59 & 0.60 \\
\hline & Control 50\% & 27.8 & 37.8 & 1.61 & 1.60 & 7.38 & 7.10 & 0.74 & 1.12 & 0.52 & 0.50 & 0.40 & 0.39 \\
\hline & $50 \%$ mineral+ PGPR & 29.3 & 29.45 & 1.57 & 1.57 & 7.34 & 7.25 & 1.15 & 1.16 & 0.65 & 0.59 & 0.52 & 0.51 \\
\hline & $50 \%$ mineral + Humic & 25.8 & 26.14 & 1.55 & 1.52 & 7.28 & 7.08 & 1.19 & 1.18 & 0.71 & 0.65 & 0.50 & 0.50 \\
\hline & PGPR+ Humic & 30.3 & 31.99 & 1.48 & 1.41 & 7.11 & 6.98 & 1.15 & 1.20 & 0.65 & 0.54 & 0.52 & 0.53 \\
\hline \multirow{6}{*}{$\begin{array}{c}\text { With } \\
\text { vermicompost }\end{array}$} & $100 \%$ mineral + verm & 33.11 & 34.06 & 1.45 & 1.39 & 7.33 & 7.28 & 1.18 & 1.18 & 0.72 & 0.73 & 0.61 & 0.62 \\
\hline & $50 \%$ mineral + verm & 28.98 & 29.66 & 1.48 & 1.42 & 7.34 & 7.29 & 0.99 & 1.1 & 0.70 & 0.70 & 0.55 & 0.56 \\
\hline & $50 \%$ min.+PGPR+verm & 42.34 & 44.87 & 1.38 & 1.36 & 7.10 & 6.99 & 1.28 & 1.29 & 0.81 & 0.83 & 0.66 & 0.67 \\
\hline & $50 \%$ min. + Humi + verm & 34.64 & 35.14 & 1.33 & 1.28 & 6.97 & 6.86 & 1.37 & 1.40 & 0.81 & 0.84 & 0.62 & 0.63 \\
\hline & PGPR+ Humi+ verm & 42.11 & 43.93 & 1.31 & 1.30 & 6.97 & 6.86 & 1.42 & 1.44 & 0.87 & 0.88 & 0.63 & 0.66 \\
\hline & L.S.D 0.05 & 0.92 & 0.92 & 0.15 & 0.12 & 0.10 & 0.34 & Ns & Ns & 0.071 & 0.064 & 0.028 & 0.111 \\
\hline
\end{tabular}

Soil organic matter (SOM), Electric conductivity (E.C) and soil reaction (pH), means designated by the same letter within each column are Ns: not significantly or. Insignificant.

Table 4: Effect of PGPR, humic with or without vermicompost on soil biological characters after cotton harvesting in 2018 and 2019 seasons.

\begin{tabular}{|c|c|c|c|c|c|c|c|c|c|c|c|c|c|c|c|c|}
\hline \multirow{3}{*}{$\begin{array}{c}\text { Characters } \\
\text { Treatment } \\
\text { Seasons } \\
\end{array}$} & \multicolumn{4}{|c|}{$\begin{array}{c}\text { Total Bact. Counts } \\
\left(10^{7} \mathrm{cfu} \mathrm{g}^{-1} \text { soil }\right)\end{array}$} & \multicolumn{4}{|c|}{$\begin{array}{c}\text { Total Fungi } \\
\left(10^{4} \text { cfu g }^{-1} \text { soil }\right)\end{array}$} & \multicolumn{5}{|c|}{$\begin{array}{c}\text { Total action } \\
\left(10^{3} \mathrm{cfu} \mathrm{g}^{-1} \text { soil }\right) \\
\end{array}$} & \multicolumn{3}{|c|}{$\begin{array}{l}\text { CO2 evolution } \\
\left(\mathrm{mg100} \mathrm{g} \mathrm{soil}^{-1}\right)\end{array}$} \\
\hline & \multicolumn{2}{|c|}{ With* } & \multicolumn{2}{|c|}{ Without** } & \multicolumn{2}{|c|}{ With } & \multicolumn{2}{|c|}{ Without } & \multicolumn{2}{|c|}{ With } & \multicolumn{3}{|c|}{ Without } & \multirow{2}{*}{$\begin{array}{c}\text { With } \\
2019 \\
\end{array}$} & \multicolumn{2}{|c|}{ Without } \\
\hline & 2018 & 2019 & 2018 & 2019 & 2018 & 2019 & 2018 & 2019 & 2018 & 2019 & 2018 & 2019 & 2018 & & 2018 & 2019 \\
\hline Control $^{1} 100 \%$ & 17 & 19 & 13 & 13 & 33 & 35.1 & 26 & 29.0 & 24.9 & 26.0 & 18.0 & 19.0 & 18.4 & 18.8 & 17.8 & 17.9 \\
\hline Control $^{2} \mathbf{5 0} \%$ & 12 & 14 & 11 & 12 & 23.8 & 27.1 & 20 & 22.0 & 20.6 & 21.0 & 17.0 & 16.0 & 17.2 & 17.6 & 15.5 & 15.6 \\
\hline $\begin{array}{l}50 \% \text { mineral + } \\
\text { PGPR }\end{array}$ & 38 & 40 & 27 & 29 & 58.1 & 59.9 & 49 & 51.0 & 54.1 & 59.0 & 40.0 & 43.0 & 30.6 & 30.8 & 27.5 & 27.9 \\
\hline $\begin{array}{l}50 \% \text { mineral + } \\
\text { Humic }\end{array}$ & 27 & 33 & 20 & 23 & 45.3 & 46.8 & 34 & 36.4 & 43.1 & 47.0 & 33.1 & 38.1 & 28.6 & 28.8 & 24.9 & 26.0 \\
\hline PGPR+ Humic & 42 & 43 & 29 & 31 & 62.1 & 67.9 & 55 & 56.9 & 69.1 & 70.0 & 44.0 & 49.0 & 34.0 & 34.3 & 30.6 & 30.9 \\
\hline L.S.D 0.05 & \multicolumn{2}{|c|}{3.5} & \multicolumn{2}{|c|}{3.0} & \multicolumn{2}{|c|}{4.5} & \multicolumn{2}{|c|}{ Ns } & \multicolumn{2}{|c|}{29.0} & \multicolumn{3}{|c|}{2.2} & 0.92 & \multicolumn{2}{|c|}{0.73} \\
\hline
\end{tabular}

Means designated by the same letter within each column are Ns: not significantly or. Insignificant.

* With vermicompost, ** without vermicompost 
Table 5: Chlorophyll A, B (mg/g dry weight), Carotenoids (mg/g dry weight) and Total phenols (mg/g dry weight) as affected by fertilization and vermicompost treatments in 2018 and 2019 seasons.

\begin{tabular}{|c|c|c|c|c|c|c|c|c|c|c|c|c|c|c|c|c|}
\hline \multirow{3}{*}{ Treatment } & \multicolumn{4}{|c|}{$\begin{array}{r}\text { Chlorophyll A } \\
\text { (mg/g dry wt.) }\end{array}$} & \multicolumn{5}{|c|}{$\begin{array}{r}\text { Chlorophyll } B \\
\text { (mg/g dry wt.) }\end{array}$} & \multicolumn{3}{|c|}{$\begin{array}{c}\text { Carotenoids } \\
(\mathrm{mg} / \mathrm{g})\end{array}$} & \multicolumn{4}{|c|}{$\begin{array}{l}\text { Total phenol } \\
\text { (mg/g dry wt.) }\end{array}$} \\
\hline & \multicolumn{2}{|c|}{ With* } & \multicolumn{2}{|c|}{ Without** } & \multicolumn{2}{|c|}{ With } & \multicolumn{3}{|c|}{ Without } & \multirow{2}{*}{$\frac{\text { With }}{2019}$} & \multicolumn{2}{|c|}{ Without } & \multicolumn{2}{|c|}{ With } & \multicolumn{2}{|c|}{ Without } \\
\hline & 2018 & 2019 & 2018 & 2019 & 2018 & 2019 & 2018 & 2019 & 2018 & & 2018 & 2019 & 2018 & 2019 & 2018 & 2019 \\
\hline Control $^{1} 100 \%$ & 3.90 & 3.90 & 3.90 & 3.80 & 3.60 & 3.70 & 3.45 & 3.50 & 0.60 & 0.50 & 0.51 & 0.49 & 27.0 & 25.0 & 24.0 & 23.0 \\
\hline Control $^{2} 50 \%$ & 3.80 & 3.80 & 3.80 & 3.70 & 3.50 & 3.45 & 3.30 & 3.22 & 0.30 & 0.30 & 0.22 & 0.21 & 24.0 & 23.0 & 23.0 & 22.0 \\
\hline $\begin{array}{l}\text { 50\% mineral + } \\
\text { PGPR }\end{array}$ & 5.0 & 5.0 & 4.9 & 3.75 & 3.50 & 3.53 & 3.40 & 3.30 & 0.40 & 0.31 & 0.30 & 0.25 & 26.0 & 24.0 & 23.0 & 23.0 \\
\hline $\begin{array}{l}50 \% \text { mineral+ } \\
\text { Humic }\end{array}$ & 4.30 & 4.9 & 5.0 & 4.0 & 3.55 & 3.50 & 3.37 & 3.40 & 0.38 & 0.30 & 0.31 & 0.31 & 25.0 & 23.0 & 25.0 & 25.0 \\
\hline PGPR+ Humic & 5.30 & 5.10 & 4.10 & 5.10 & 3.8 & 3.75 & 3.50 & 3.50 & 0.70 & 0.69 & 0.52 & 0.58 & 27.0 & 26.0 & 26.0 & 27.0 \\
\hline
\end{tabular}

* With vermicompost, ${ }^{* *}$ without vermicompost

Table 6: Effect of fertilization and vermicompost treatments on yield and yield component in 2018 and 2019 seasons.

\begin{tabular}{|c|c|c|c|c|c|c|c|c|c|c|c|c|c|c|c|c|c|}
\hline \multirow{3}{*}{ Treatment } & \multirow{3}{*}{$\begin{array}{c}\text { Characters } \\
\text { Seasons }\end{array}$} & \multicolumn{4}{|c|}{$\begin{array}{c}\text { Boll weight } \\
\left(\mathrm{g}^{-1}\right)\end{array}$} & \multicolumn{4}{|c|}{$\begin{array}{c}\text { Lint percentage } \\
(\%)\end{array}$} & \multicolumn{4}{|c|}{$\begin{array}{c}\text { Seed Index } \\
\text { (g.) }\end{array}$} & \multicolumn{4}{|c|}{$\begin{array}{c}\text { Seed cotton yield } \\
\text { (kentar / fed) }\end{array}$} \\
\hline & & \multicolumn{2}{|c|}{ With } & \multicolumn{2}{|c|}{ Without } & \multicolumn{2}{|c|}{ With } & \multicolumn{2}{|c|}{ Without } & \multicolumn{2}{|c|}{ With } & \multicolumn{2}{|c|}{ Without } & \multicolumn{2}{|c|}{ With } & \multicolumn{2}{|c|}{ Without } \\
\hline & & 2018 & 2019 & 2018 & 2019 & 2018 & 2019 & 2018 & 2019 & 2018 & 2019 & 2018 & 2019 & 2018 & 2019 & 2018 & 2019 \\
\hline Control $^{1} 100 \%$ & & 3.2 & 3.3 & 3.0 & 3.0 & 38.0 & 37.2 & 37.4 & 37.5 & 10.0 & 10.2 & 10.1 & 10.3 & 10.8 & 11.1 & 10.3 & 10.3 \\
\hline Control $^{2} 50 \%$ & & 3.0 & 3.1 & 2.9 & 2.91 & 37.5 & 37.6 & 36.2 & 37.3 & 9.8 & 10.0 & 9.3 & 9.5 & 8.5 & 8.9 & 8.1 & 8.3 \\
\hline $50 \%$ mineral+PGPR & & 3.1 & 3.2 & 3.0 & 3.0 & 36.8 & 36.9 & 36.3 & 36.4 & 10.2 & 9.7 & 9.8 & 10.1 & 11.2 & 11.5 & 10.1 & 10.5 \\
\hline $50 \%$ mineral+Humic & & 3.1 & 3.2 & 3.0 & 2.98 & 36.7 & 36.8 & 36.4 & 36.5 & 9.9 & 9.9 & 9.3 & 9.4 & 10.8 & 11.5 & 10.7 & 10.9 \\
\hline PGPR+ Humic & & $\underline{3.3}$ & $\underline{3.35}$ & 3.1 & 3.1 & 38.8 & 38.3 & 37.1 & 36.5 & 10.0 & 10.2 & 10.0 & 10.2 & 11.8 & 12.1 & 10.8 & 11.0 \\
\hline L.S.D 0.05 & & \multicolumn{2}{|c|}{0.18} & \multicolumn{2}{|c|}{0.15} & \multicolumn{2}{|c|}{ Ns } & \multicolumn{2}{|c|}{$\mathrm{Ns}$} & \multicolumn{2}{|c|}{0.23} & \multicolumn{2}{|c|}{0.20} & \multicolumn{2}{|c|}{0.16} & \multicolumn{2}{|c|}{0.11} \\
\hline
\end{tabular}

Means designated by the same letter within each column are Ns: not significantly or. Insignificant.

* With vermicompost, ** without vermicompost 
significant increase in microbial population total bacteria count, fungi and actinomycetes was observed with the addition of vermicompost. Concerning, the seed index significant results pointed to that treatment (PGPR + Humic acid) with or without vermicompost proved the superior in both seasons. These results are in harmony with (Ahmed et al., 2020)

It's obvious from Table (7) that tested treatments gave significant effect on micronaire value and maturity characters. Adding (PGPR + humic acid) increased micronaire value (4.6 and 4.5), (0.98 and 0.99 ) in both years under the two cases of vermicompost application respectively, then the recommended. However, the treatment $\left(50 \%\right.$ of the recommend mineral) dose (control $\left.{ }^{2}\right)$ without vermicompost gave the lowest values of micronaire reading (3.7 and 3.5), (0.90 and 0.89) in both seasons under the two cases respectively. It worthy, to mention that micronaire value gave both of the intrinsic fineness and maturity so, the increasing in micronaire value in this case was due to increasing in maturity since we use one genotype as indicated from maturity ratio results in the same table which usually follow the same trend. These results are in harmony with (Arafa 2003 and Attia et al., 2008).

Demonstrated that, the highest values of fiber strength values (44.7 and 44.9) were obtained from the treatment (PGPR + humic acid) with vermicompost in both seasons respectively. On the other hand, the lowest values of fiber strength were (39.3 and 39.5), this was due to the treatment of ( $50 \%$ of mineral fertilizer) without vermicompost indicating the benefits and positive effect of bio-fertilizer is such able when the organic matter is found this may be due to that PGPR works in its best way when the $\mathrm{pH}$ of soil is acidic due to the decrease in soil $\mathrm{pH}$ due to humic acid the composition of vermicompost active the soil bacteria and the ability of root uptake which reflected in plant metabolism so by using the combination $100 \%$ of mineral fertilization without any deterioration in fiber . With concern to fiber elongation \% there were no significant differences between the means of the fiber elongation \% due to the treatments applied during the study. These results are in harmony with (Ahmed et al., 2020)

It's clear in Table (8): that the combination (PGPR + humic acid) with vermicompost increased the fiber length $(2 \mathrm{~mm})$ in 2018 season and $(1 \mathrm{~mm})$ in 2019 season than the control ${ }^{1}$ (recommended dose) in presence of vermicompost. Also, it accompanied by some increment in fiber uniformity index which recorded ( $88.5 \%$ and $88.3 \%$ ) in 2018 and 2019 respectively. The (50\% of recommended dose) give the lowest reading in both seasons with or without vermicompost but also adding PGPR to $50 \%$ of the recommended surpassed the treatment (humic acid with $50 \%$ of the recommended) in case of the soil applied with vermicompost. On the other hand, (humic acid with $50 \%$ of recommended) was better than the previous in case of the soil without vermicompost.

It could be attributed to that plants grown under bio-fertilizer treatment only was suffering from lack in nutrient which accompanied with reduction in fiber maturity and strength. So, they became easier to break during ginning which causes decreasing in fiber length and uniformity\%. These results are in conformity with those revealed by: (Ahmed et al., 2020 and Neeru et al., 2005). The interaction between fertilizers and vermicompost was not significant. The treatments of vermicompost (75.1) were usually better than those without vermicompost (75.0) for reflectance degree percentage in addition, the treatment (PGPR + humic Acid with vermicompost) gave the highest values of Rd\% (76.9) than the other fertilizers treatments. In contrast, the lowest value of $\mathrm{Rd} \%$ was (73.0) for the mean of fertilizer treatment control ${ }^{2}$ without vermicompost. On the contrary, yellowness degree $(+b)$ behaved in opposite trend for this concern. This could be ascribed to the increase in fiber maturity as a result of good accumulation of carbohydrates which increase the cellulosic materials as found in plants grow under deficient of growth elements. In general, it is from this study can be drawn that adding vermicompost achieved the highest content of soil organic matter adding bacterial strains led to increase the soil biological activity this reflected directly on all the soil and plant characters under the study. The treatment of mixed of bacterial strains (PGPR) and humic acid in the presence of vermicompost was the best for the cotton crop yield and fiber quality as well as the properties of soil chemical and biological artillery compared to the control treatment. These results are in conformity with those revealed by: (Mahmoud et al., 2019) 
Middle East J. Appl. Sci., 11(3): 774-784, 2021

Table 7: Effect of fertilization and vermicompost treatments on fiber properties in 2018 and 2019 seasons

\begin{tabular}{|c|c|c|c|c|c|c|c|c|c|c|c|c|c|c|c|c|c|}
\hline \multirow{3}{*}{ Treatment } & \multirow{3}{*}{$\begin{array}{c}\text { Characters } \\
\text { Seasons }\end{array}$} & \multicolumn{4}{|c|}{ Micronaire value } & \multicolumn{4}{|c|}{ Maturity ratio } & \multicolumn{4}{|c|}{$\begin{array}{l}\text { strength } \\
\text { (g/tex) }\end{array}$} & \multicolumn{4}{|c|}{$\begin{array}{c}\text { Elongation } \\
\% \\
\end{array}$} \\
\hline & & \multicolumn{2}{|c|}{ With* } & \multicolumn{2}{|c|}{ Without** } & \multicolumn{2}{|c|}{ With } & \multicolumn{2}{|c|}{ Without } & \multicolumn{2}{|c|}{ With } & \multicolumn{2}{|c|}{ Without } & \multicolumn{2}{|c|}{ With } & \multicolumn{2}{|c|}{ Without } \\
\hline & & 2018 & 2019 & 2018 & 2019 & 2018 & 2019 & 2018 & 2019 & 2018 & 2019 & 2018 & 2019 & 2018 & 2019 & 2018 & 2019 \\
\hline Control $^{1} 100 \%$ & & 4.2 & 3.9 & 4.1 & 4.0 & 0.98 & 0.97 & 0.98 & 0.98 & 44.5 & 44.6 & 44.4 & 44.5 & 7.1 & 7.3 & 7.2 & 7.2 \\
\hline Control $^{2} 50 \%$ & & 3.8 & 3.8 & $\underline{3.7}$ & $\underline{3.5}$ & $\underline{0.90}$ & $\underline{0.89}$ & 0.88 & 0.80 & 39.7 & 39.8 & $\underline{39.3}$ & $\underline{39.5}$ & 6.8 & 7.1 & 6.6 & 6.7 \\
\hline $50 \%$ mineral + PGPR & & 3.9 & 4.2 & 3.8 & 3.8 & 0.91 & 0.92 & 0.90 & 0.90 & 43.2 & 43.4 & 42.0 & 44.4 & 7.2 & 6.6 & 7.1 & 7.2 \\
\hline $50 \%$ mineral+Humic & & 3.8 & 4.1 & 4.0 & 3.9 & 0.92 & 0.93 & 0.90 & 0.90 & 44.1 & 43.5 & 42.2 & 44.3 & 7.1 & 6.9 & 7.1 & 6.7 \\
\hline PGPR+ Humic & & $\underline{4.6}$ & $\underline{4.5}$ & 4.3 & 4.4 & $\underline{0.98}$ & $\underline{0.99}$ & 0.99 & 0.98 & $\underline{44.7}$ & $\underline{44.9}$ & 44.7 & 44.7 & 7.2 & 7.5 & 7.1 & 7.1 \\
\hline L.S.D 0.05 & & & & & & & & & & & & & 17 & & & & \\
\hline
\end{tabular}

Means designated by the same letter within each column are Ns: not significantly or. Insignificant.

* With vermicompost, ** without vermicompost

Table 8: Effect of fertilization and vermicompost treatments on fiber properties in 2018 and 2019 seasons

\begin{tabular}{|c|c|c|c|c|c|c|c|c|c|c|c|c|c|c|c|c|}
\hline \multirow[b]{2}{*}{ Treatment } & \multicolumn{4}{|c|}{ UHM (mm) } & \multicolumn{4}{|c|}{ UI \% } & \multicolumn{4}{|c|}{ RD\% } & \multicolumn{4}{|c|}{$+\mathbf{b}$} \\
\hline & \multicolumn{2}{|c|}{ With } & \multicolumn{2}{|c|}{ Without } & \multicolumn{2}{|c|}{ With } & \multicolumn{2}{|c|}{ Without } & \multicolumn{2}{|c|}{ With } & \multicolumn{2}{|c|}{ Without } & \multicolumn{2}{|c|}{ With } & \multicolumn{2}{|c|}{ Without } \\
\hline Seasons & 2018 & 2019 & 2018 & 2019 & 2018 & 2019 & 2018 & 2019 & 2018 & 2019 & 2018 & 2019 & 2018 & 2019 & 2018 & 2019 \\
\hline Control $^{1} 100 \%$ & 33.3 & 33.4 & 33.1 & 33.3 & 88.0 & 87.1 & 87.7 & 87.0 & 75.1 & 75.3 & 74.7 & 74.8 & 8.8 & 8.9 & 8.8 & 8.9 \\
\hline Control $^{2} 50 \%$ & 31.3 & 29.9 & 29.7 & 29.8 & 83.5 & 83.7 & 83.2 & 83.1 & 72.4 & 73.3 & 73.0 & 73.0 & 8.9 & 8.9 & 9.0 & 8.8 \\
\hline $50 \%$ mineral+PGPR & 32.2 & 32.4 & 31.0 & 31.1 & 86.0 & 86.7 & 85.6 & 85.6 & 73.9 & 74.3 & 73.2 & 72.4 & 8.9 & 8.9 & 8.9 & 8.9 \\
\hline $50 \%$ mineral+Humic & 31.8 & 32.5 & 32.7 & 31.9 & 85.8 & 85.9 & 86.0 & 86.3 & 74.7 & 74.0 & 75.6 & 73.8 & 8.9 & 8.9 & 8.8 & 8.8 \\
\hline PGPR+ Humic & 35.3 & 34.4 & 32.9 & 33.3 & 88.5 & 88.3 & 87.4 & 87.8 & 76.9 & 75.2 & 75.0 & 74.5 & 8.9 & 8.9 & 8.8 & 8.8 \\
\hline L.S.D 0.05 & & & & & & & & & & & & Js & & & & Js \\
\hline
\end{tabular}

Means designated by the same letter within each column are Ns: not significantly or. Insignificant.

* With vermicompost, ** without vermicompost 


\section{Conclusion}

The treatment of PGPR and Humic acid in the presence of vermicompost increased the soil content of N, P, K along with the soil softness, soil total fungi, bacteria actinomycetes counts, as well as, boll weight, lint percentage, seed index and seed cotton yield, the Leaf chemical analysis and fiber physical properties. All the treatments led to an increase in soil biological activity in terms of increasing the total bacterial, total Fungi counts. So, we can use this treatment safely to produce bioorganic cotton and a friend of the environment.

\section{References}

Abeer S. Arafa, Heba M.A. Khalil and Sana G. Gebaly, 2013. Impact of eco- friendly fertilizers and rice straw on cotton yield and fiber physical properties. International Science and Investigation Journal, 8(2): 2251-8576

Ahmed, H.S.A., 2002. Botanical studies on growth and flower abortion in cotton (Gossypium barbadense cv.) Plants. Msc. Dept. of Agric Botany. Fac. of Agric. Moshtohor, Zagazig Univ. Benha branch, 3-4

Ahmed, H.S.A., 2010. Effect of some treatments on growth and productivity in Egyptian cotton. Phd. Dept. of Agric Botany. Fac. of Agric. Moshtohor, Benha Univ., 4-6

Ahmed, H.S.A., Mona H.A. and W.M. Yehia, 2020. Effect of Bio- fertilizer on yield components and fiber quality of some Egyptian cotton genotypes Plant Archives, 20(2): 9575-9583

Ahmed, H.S.A., Mona H.A. and Heba S.A. El-Desoukey, 2020. Effect of nano-fertilization and some bio-fertilizer on growth yield and fiber quality of Egyptian cotton. Annals of Agric. Sci., Moshtohor, 57 (3):661-668.

Ahmed, H.S.A., R.M. Zewail, Hala A., A.F. Ghazal, K. Botir and W.P. Kee, 2019. Promotion of growth and yield attributes of Egyptian cotton by Bacillus strains in combination with mineral fertilizers. Journal of Plant Nutrition, 1-26.

Ambergerig, A., 1993. Dynamics of nutrients and reaction of fertilizers applied on the environment. Proc. of German/ Egyptian/ Arab Workshop in Cairo and Ismailia, Egypt. 6-17: 41-60.

Ansari, R.A., I. Mahmood and S. Springer, 2019. ${ }^{a}$ Plant Health Under Biotic Stress, 1: Organic Strategies.

Ansari, R.A., R. Rizvi, A. Sumbul, I. Mahmood and S. Springer, 2017. PGPR current vogue in sustainable crop production. Probiotics and Plant Health, 455-472.

Ansari, R.A., I. Mahmood and S. Springer, 2019b. Plant Health under Biotic Stress: Volume 2: Microbial Interactions.

Arafa, A.S. and S.G. Gebaly, 2007. Cotton yield and fiber quality variation related to fertilization with poultry litter, microbien and mineral nitrogen. The first Arab Conf. on Environ. St. and Res. "The contemporary and future environmental issues in the Arab region" Ain shams Univ.

Arafa, H.M., 2003. Influence of irrigation and fertilization sources on yield and fiber characters of Giza 89 cotton cultivar preceded by Egyptian clover or barley. M.Sc. Thesis, Fac. of Agric., Cairo Univ., Egypt.

Arnon, D.I., 1949. Copper enzymes in isolated chloroplast. Plant physiol., 24:1-15.

ASTM, 1986. American society for testing materials, D-4605. U.S.A.

Attia, A.N., M.S. Sultan, E.M. Said, A.M. Zina and A.E. Khalifa, 2008. Effect of the first irrigation time and fertilization treatments on the growth, yield, yield component and trails of cotton. Journal of Agronomy, 7(1): 70-75.

Bhattacharyya, P.N. and D.K. Jha, 2012. Plant growth-promoting rhizobacteria (PGPR) emergence in agriculture. World J. Microb. Biot., 28(4):327-1350.

Dhale, D.A., S.N. Chatte and V.T. Jadhav, 2011. Response of bioinoculents on growth, yield and fiber quality of cotton under irrigation. Agricultural and biology journal of north America. Science $\mathrm{Hu}$, http://www.scihub.org/ABJNA

El-Maas, I.M. Enshrah and Fatma, S.H. Ismail, 2016. Impact of bio fertilizer ,Humic acid and compost tea application on soil properties and Egyptian clover productivity under slaime soil condition. J. Soil and Agric. Eng, Mansura university, 7 (9): 611-622. 
El-Shazly, M.W.M., Y.F.A. Ata Allah and A.M. Abd El All, 2019. Response of Cotton Plant to Fertilization Sources and Foliar Spraying with Humic Acid. Agri. Res. \& Tech: Open Access J., 20(2): 556120.

Fataftah, A.K., D.S. Watia, B.G. Ains and S.I. Kotob, 2001. Comparative evaluation of known liquid humic analysis method. Special Publication-Royal Society of Chemistry, 273: 337-344.

Heba, M.A. Khalil and Rokaya M. Hassan, 2015. Raising the Productivity and Fiber Quality of Both White and Colored cotton Using Eco-Friendly Fertilizers and Rice Straw. International Journal of Plant Research, 5(5): 122-135.

ICOF., International Conference on Organic Farming, 2010. Friendship Hall, Khartoum, Sudan, 6 - 7. Jackson, M.L., 1973. Soil chemical analysis perenticet Hall, my. Englewood Cliffs, N. J.,331

Jackson, M.L., 1976. Soil chemical analysis. Prentice- Hall, Inc. Engle Wood Cliffs, N.J., 498.

Kevin, V.J., 2003. Plant growth promoting rhizobacteria as bio-fertilizers. Plant and Soil, 255:571585 .

Mitkees, R.A., M.S. Ajman, A.M.K. Eissa and S.K. Mahmoud, 1996. Use of nitrogen bio-fertilizer requirements. Nile valley and Red Sea Regional program, Eight, Ann. Coordination Meeting, Egypt, 15-19: 140-146.

M-Stat 6.311, C.C.W., 1998-2005. Cohort software798light house Ave. PMB320, Monterey, CA93940, and USA. http://www. cohort. com /Download M-Stat Part 2. html

Neeru Narula, B.S., V.K. Saharan, B. Ranjana, L.K. Bishnoi, B.P. Lather and Lakshminarayana, 2005. Impact of Biofertilizers on grain yield in spring wheat under varying fertility B.s. conditions and wheat-cotton rotation. Archives of Agronomy and Soil Science, 51(1):69-77

Rolbelen, G., 1957. Mntersuchungen and strohlenin duzieten blatt arbumutantenvan arbidopois Thaliana (l.) Verbungsie (Germany).

Sánchez Rodríguez, R., A.J.A. Pino, P.C. Vallin, R.M.E. Pérez, S.Y. Iznaga and R.F. Malpartida, 2002. Effects of the natural fungicide F20 on black Sigatoka disease (Mycosphaerella fijiensis Morelet) on plantain (AAB) and banana (AAA). IN FOM USA 11(1): 14-16.

Shivalingaiah, M., 2007. Effect of nutrient management and plant protection practices in organic cotton production (Gossypium spp.) M.Sc. Thesis, University of Agricultural Sciences, Dharwad

Simon, T.S. and A.F. Ross, 1971. Changes in phenol metabolism associated with inclosed systemic resistance to tobacco mosic virus Sum sun NN tobacco phytopathology. 61: 126-1265.

Snedecor, G.W. and W.G. Cochran, 1981. Statistical method. $7^{\text {th }}$. Iowa State Univ. Press. Iowa, U.S.A.

Sofy, A.R., M.S. Attia, A.M.A. Sharaf and K.A. El-Dougdoug, 2014b. Potential impacts of seed bacterization or salix extract in faba bean for enhancing protection against bean yellow mosaic disease. Nat., Sci., 12 (10):67-82.

Twewaadha, E. and S.R. Alweendo, 2007. The Effect of nitrogen, phosphorus and potassium fertilizers on cotton cultivar (TETRA). The World Cotton Research Conference-4: 10-14.

Waller, R.A. and D.B. Duncan, 1969. A bays rule for the symmetric multiple comparison problem. Am. State Assoc. J., 1469-1503.

Youssef, M.M.A. and M.F.M. Eissa, 2014. Bio-fertilizers and their role in management of plant parasitic nematodes, E. J. Biotechnol. Pharm. Res., 5: 1-6 